\title{
Effects of forest disturbance on seasonal soil temperature changes in the Tatra Mountains in southern Poland
}

\author{
Joanna Paulina Siwek \\ Jagiellonian University in Kraków, Institute of Geography and Spatial Management, Department of Hydrology, \\ ul. Gronostajowa 7, PL-30-387 Kraków, Poland
}

\begin{abstract}
The purpose of the study was to examine the effects of forest disturbance on seasonal changes in soil temperature in the Tatra Mountains (Poland). In the years 2015-2020 soil temperatures were measured at a depth of $20 \mathrm{~cm}$ on north- and south-facing mountain slopes in a catchment where forest was disturbed by hurricane-force winds in 2013 and in a control neighboring woodland catchment. The effect of forest disturbance was manifested first and foremost in an increase in the soil temperature during the summer months - average by 1.8 to $2.4^{\circ} \mathrm{C}$ on a south-facing mountain slope - and by about $1^{\circ} \mathrm{C}$ on a north-facing slope. The buffer effect of forest on soil temperature can be observed via lower coefficients of correlation between soil temperature and air temperature in a woodland catchment versus a disturbed catchment in the summer. In the winter, the effect of forest disturbance on soil temperature was less pronounced than in the summer. Small differences in soil temperature in the winter between the woodland catchment and the disturbed catchment were associated with the presence of snow cover and its capacity to yield thermal insulation. Good insulation of the soil from the atmosphere generated by snow cover yielded a very weak relationship between soil temperature and air temperature in the winter. In springtime the soil temperature increased the fastest on a south-facing slope in the disturbed catchment while in the autumn season, soil temperatures declined most rapidly on a slope facing north in the disturbed catchment.
\end{abstract}

Key words: soil temperature; forest disturbance; windthrow; seasonal changes; Tatra Mountains

Editor: Erika Gömöryová

\section{Introduction}

The increase in air temperature observed across the Earth in the last few decades (Allen et al. 2018) is a cause of the rise in soil temperature. This pattern was examined in studies in the United States, where the soil temperature at most of nearly 300 stations has shown a trend of warming in the last 35 years, with the average warming rate at $0.38^{\circ} \mathrm{C}$ per 10 years (Hu \& Feng 2003). The increase in soil temperature and the associated soil drought have served as the cause of forest disturbance in many parts of the world over the last few decades (Allen et al. 2010; Anderegg et al. 2012; Martinez-Vilalta 2012; Steinkamp et al. 2015). Forest disturbance as well as deforestation drive an array of feedback mechanisms. For example, they generally lead to a continuous increase in the soil temperature primarily due to an increase in near-ground solar radiation (Anderegg et al. 2012). The rise in soil temperature due to forest disturbance and deforestation triggers changes in the functioning of ecosystems. Water circulation patterns in catchments change mostly due to an increase in evaporation and decline in transpiration during low flow periods (Likens et al. 1970; Jewett et al. 1995; Anderegg et al. 2012). However, according to Gholami (2013), Hlásny et al. (2015) and Khaleghi (2017), deforestation causes increase in peak discharge and runoff volume during rainfall events. Forest disturbance along with the soil warming leads to changes in carbon cycling (Davidson \& Janssens 2006; Allen 2009), as does nutrient cycling (Anderegg et al. 2012) and soil respiration (Londo et al. 1999; Schlesinger \& Andrews 2000; Ney et al. 2019).

Most studies indicate that forest disturbance and deforestation cause a marked rise in soil temperature during the summer months (Donnelly et al. 1991; Bhatti et al. 2000; Hu et al. 2003; Moroni et al. 2009) and minor changes in the winter months (Donnelly et al. 1991; Hashimoto \& Suzuki 2004; Moroni et al. 2009). However, Whitson et al. (2005) measured distinctly higher soil temperatures at harvested sites than at forest sites during snowmelt. Iwahana et al. (2005) also argue that 
clear-cutting enhances ground thawing and the depth of the soil active layer in areas underlain by permafrost, for example in the eastern Russian region of Siberia. Snow cover also plays an important role in seasonal changes in soil temperature. The depth of snow together with snow thermal conductivity play a key role in snow thermal insulation, as noted by Iwahana et al. (2005), Mellander et al. (2005) and Hu et al. (2013). Work by Mellander et al. (2005) showed that the nature of tree stands determines the thickness of snow cover in a woodland area. For example, an open tree stand together with a low surface area covered by its canopy ultimately result in thicker layers of snow.

The purpose of the present study was to investigate the effect of forest disturbance triggered by natural causes - such as a hurricane-force wind - on seasonal changes in soil temperature in a mountain region where tree stands are dominated by spruce. An increase in soil temperature after forest disturbance was expected; however, the key questions were the following: (i) What was the magnitude of the increase? (ii) How does slope exposure affect this magnitude? These are important questions today, as forest disturbance may increase soil warming caused by global climate warming. Despite the availability of several global soil surface temperature databases based on satellite products, according to Cassardo et al. (2018), there is still a lack of observational data on soil temperature profiles, especially for the root layer zone.

Initial research work focused on a comparison of soil temperature in a catchment where forest was disturbed by hurricane-force winds in 2013 and soil temperature in a neighboring undisturbed woodland catchment. In the course of the research a unique opportunity presented itself. It became possible to directly examine the effects of forest disturbance on soil temperature in the same catchment. Spruce stands in a woodland catchment experienced an attack of the bark beetle in 2018. In the following year the stands were partly overturned by high winds.

\section{Material and methods}

\subsection{Study area and meteorological conditions}

The research study was conducted in two small subcatchments: (1) disturbed catchment, and (2) control woodland catchment (Fig. 1). Both sub-catchments are located in the Kościeliski Potok catchment area in the Polish part of Western Tatra Mountains, which is protected as Tatra National Park. The woodland catchment, called the Kończysta Turnia, has a surface area of 14.1 ha, while the disturbed catchment, called Pośrednia Kopka, has a surface area of 14.4 ha. The woodland catchment is located at elevations ranging from a minimum of 968 to a maximum of $1,264 \mathrm{~m}$. The disturbed catchment is found at elevations in the range from $940 \mathrm{~m}$ to $1,200 \mathrm{~m}$. The mean gradient of the woodland catchment is $30.1^{\circ}$, and that of the disturbed catchment is $23.6^{\circ}$ (Żelazny et al. 2018). Both catchments are fragmented by narrow, deep V-shaped valleys, and are formed of sedimentary rocks: limestone, sandstone, conglomerates. These parent material rocks are covered with Rendzic Leptosols (Skeletic) and Haplic Cambisols (Eutric) (Skiba et al.
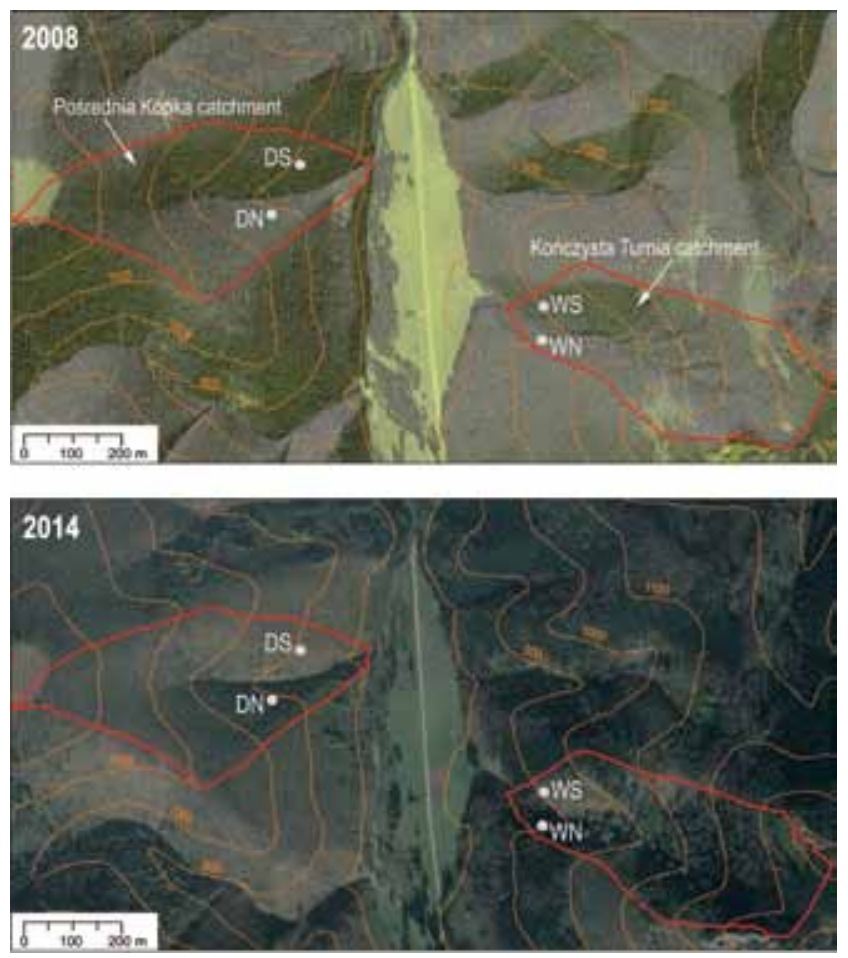

Fig. 1. Study area in 2008 and 2014. 
2015). These soils are most often 40 to $60 \mathrm{~cm}$ deep. Soils found in the woodland catchment are characterized by the occurrence of horizon $\mathrm{O}(1-5 \mathrm{~cm})$, while soils found in the disturbed catchment lack this horizon (Żelazny et al. 2018). In both catchments the mineral horizons are formed of silt loam (USDA classification); however, the A horizon is characterized by a higher proportion of sand than lower horizons (Table 1). in the study period occurred in late 2015 and early 2016 as well as late 2019 and early 2020 (Fig. 2a). According to Ustrnul et al. (2015), the mean annual atmospheric precipitation total in the study area ranges from 1,200 $\mathrm{mm}$ at lower elevations to $1,600 \mathrm{~mm}$ at high elevations. In the study period the highest atmospheric precipitation totals were recorded in the summer months (Fig. 2b). Snow cover appeared usually in October or Novem-

Table 1. Texture and carbon $(C)$ content in mineral horizons of the soils in the studied disturbed and woodland catchments - data source: Żelazny et al. (2018).

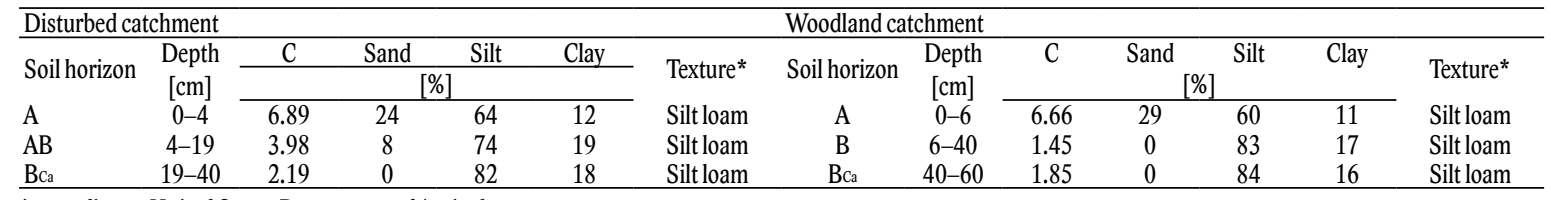

*according to United States Department of Agriculture.

The study area is located in a temperate climate zonein a moderately cool climate zone (Hess 1965). According to Żmudzka et al. (2015) the mean annual air temperature ranges from $4{ }^{\circ} \mathrm{C}$ at lower elevations to $6^{\circ} \mathrm{C}$ at high elevations. In the study period (2015-2020) the warmest months of the year were June, July, and August when the mean monthly air temperature exceeded $10^{\circ} \mathrm{C}$ (Fig. 2a). The coolest months of the year when the mean monthly air temperature decreased below $0{ }^{\circ} \mathrm{C}$ were usually December, January, and February. The warmest winters ber and melted in April or May. The largest snow depth was noted usually in December, January, and February, reaching usually more than $20 \mathrm{~cm}$. Exceptionally small snow cover depths were noted in the winter of 2015/2016 (Fig. 2c).

Originally, the study area was occupied by Dentario glandulosae-Fagetum, dominated by beech (Fagus sylvatica L.), fir (Abies alba L.), and spruce (Picea abies L.). The trees were felled at the end of the 19 th century and monocultures of spruce were planted at the begin-
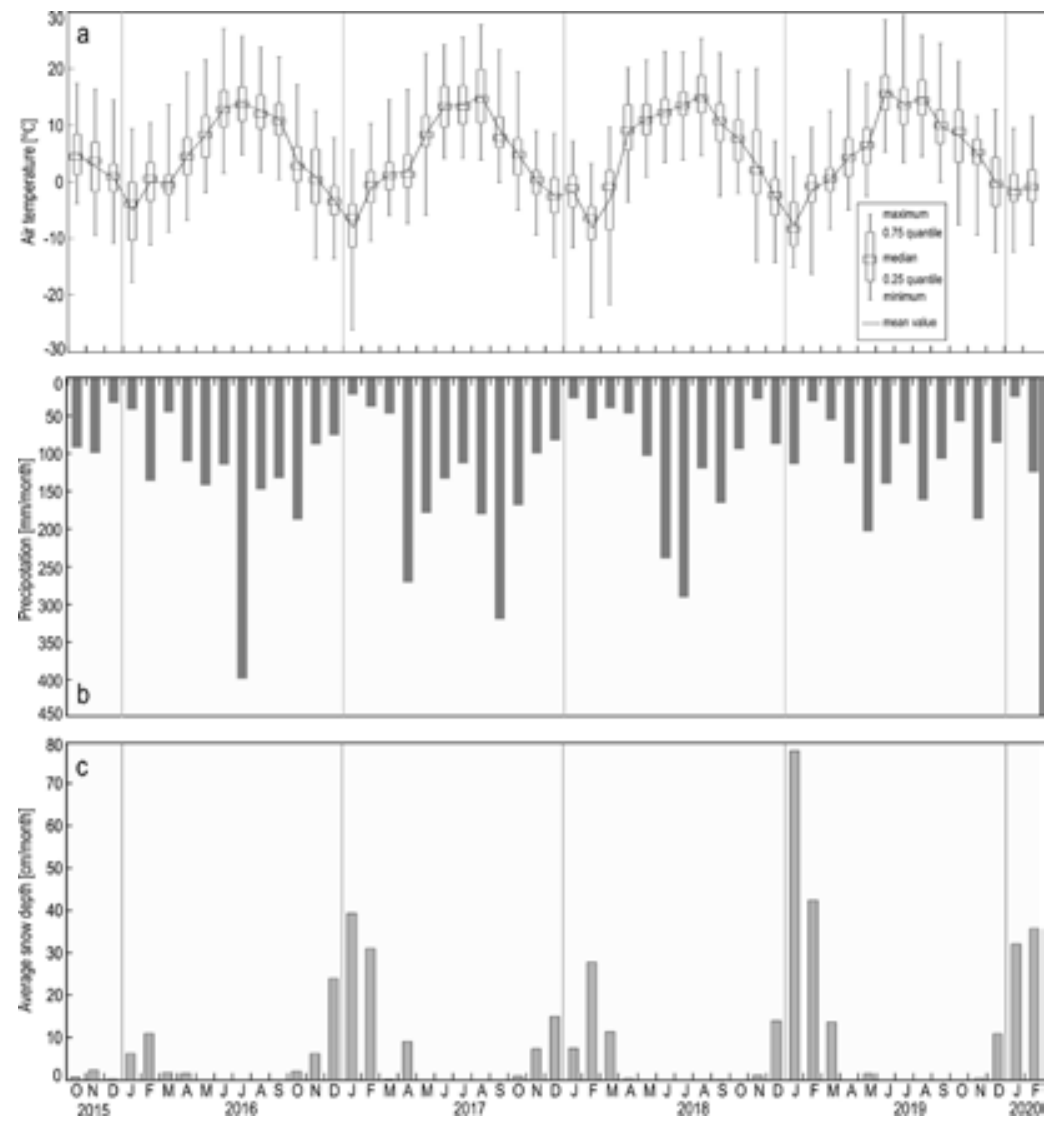

Fig. 2. Meteorological characteristics of study period: monthly air temperature (a), precipitation (b) and snow depth (c). 
ning of the 20th century (Szwagrzyk et al. 2019). The share of spruce in the studied stands exceeded $90 \%$ while the share of fir and beech did not exceed $10 \%$ (Bodziarczyk et al. 2019). Until December 2013 about 93\% of the Kończysta Turnia catchment was covered with forest, while almost $100 \%$ of the Pośrednia Kopka catchment was forestland (Fig. 1). The age of the forest ranged from 85 to 150 years. In December 2013 the Pośrednia Kopka catchmentexperienced hurricane-force winds felling $97 \%$ of its tree stands (Fig. 1). The maximum hourly average wind velocity during the windthrow event was $29 \mathrm{~m} / \mathrm{s}$ (Strzyżowski et al. 2016). In the same time period, only $13 \%$ of the forest in the Kończysta Turnia catchment became disturbed (Żelazny et al. 2018). Some of the fallen trees lying across the hillslopes in the lower and central parts of the Pośrednia Kopka catchment area were removed in 2014-2015. Fir and beech seedlings were planted in a part of this area in 2015. Research work performed in 2018 showed that $23 \%$ of the disturbed area of the Pośrednia Kopka catchment was experiencing a succession of bush vegetation and juvenile trees (Żelazny et al. 2018). Vaccinium myrtillus L., Rubus idaeus L., Athyrium distentifolium, Sorbus aucuparia L., Calamagrostis villosa, Deschampsia flexuosa L., Homogyne alpina L., and Oxalis acetosella L. are the most common species, which have emerged in the disturbed area (Szwagrzyk et al. 2019). The same study also showed that in 2018 almost 50\% of the forested area in the Kończysta Turnia catchment experienced an attack of the bark beetle. In 2019 a large percentage of trees on the south-facing slope of the woodland catchment became felled by high winds present in the area.

\subsection{Methods of measurements}

Soil temperature probes (Decagon ECH2O 5TM) were installed at two sites in each of the studied catchments. The WN and WS sites located in the studied woodland catchment represent north-facing and south-facing woodland hillslopes, respectively. The studied DN and DS sites located in the disturbed catchment represent north-facing and south-facing disturbed hillslopes, respectively. Soil temperature probes were installed in the mineral soil horizons at a depth of $20 \mathrm{~cm}$. The 20 $\mathrm{cm}$ depth was chosen to ensure that the probes will be installed in the mineral and not the organic horizons of the soil. The probes were placed at an elevation of roughly $900 \mathrm{~m}$ (Fig. 1). The technical specifications of the Decagon ECH2O 5TM probes: range from -40 to $60^{\circ} \mathrm{C}$, resolution at $0.1{ }^{\circ} \mathrm{C}, \pm 1^{\circ} \mathrm{C}$. Soil temperature measurements were collected every 10 minutes. The first probes were installed in October 2015 on a north-facing slope in the woodland catchment (WN site) and on a south-facing slope in the disturbed catchment (DS site). In April 2017 probes were installed on a north-facing slope in the disturbed catchment (DN site), while in June 2017 probes were installed on a south-facing slope in the woodland catchment (WS site). The probes experienced failures several times during the study period, which explains gaps in the data set used in the study.

Meteorologic data were obtained from weather stations run by the Institute of Meteorology and Water Management in Poland. The weather stations were located in the vicinity of the study areas examined. Air temperature data measured at a height of two meters above ground level were obtained from the Polana Chochołowska station, which is located about $6 \mathrm{~km}$ away from the studied catchments, and found at 1,147 meters of elevation. Atmospheric precipitation data and snow cover data were obtained from the Kiry-Kościelisko station located about $1 \mathrm{~km}$ away from the studied catchments at an elevation of 933 meters.

Monthly soil temperature analyses were performed only for months with a complete set of data for particular study site. The coefficient of correlation for mean daily soil temperature data for the 4 study sites with respect to mean air temperature data was calculated only for months with a complete data set from all the study sites. The Pearson correlation coefficient $(r)$ was computed. Mean daily air and soil temperatures were calculated using row data. Statistical analyses were performed in Statistica 1.3 software.

\section{Results}

The largest differences between the highest and the lowest values of the soil temperature over the course of the year were noted on the south-facing slope in the disturbed catchment (DS site), while the smallest were noted on the north-facing slope in the woodland catchment (WN site) (Fig. 3). In summer months (June to August) the soil temperature at the DS site usually exceeded $15^{\circ} \mathrm{C}$-it ranges from about $12.5^{\circ} \mathrm{C}$ up to $20^{\circ} \mathrm{C}$ in summer 2017 . Soil temperatures were lower during the same period of time on the south-facing slope in the woodland catchment (WS site), where usually did not exceed $15^{\circ} \mathrm{C}$. Soil temperatures in the summer on north-facing slopes in the woodland and disturbed catchments usually ranged from 10 to $15^{\circ} \mathrm{C}$ - exceeding the latter only in selected cases. Soil temperatures decreased below $5^{\circ} \mathrm{C}$ in all the studied catchments in wintertime, but did not normally fall below $0^{\circ} \mathrm{C}$. Only the soil temperature at the DS site decreased below $0{ }^{\circ} \mathrm{C}$ in the winter of 2015 . Soil temperatures in the spring and autumn months usually ranged from 5 to $10^{\circ} \mathrm{C}$ (Fig. 3).

The smallest monthly differences in soil temperature occurred in all the studied sites in the wintertime, as evidenced by the monthly interquartile range and monthly maximum-minimum range (Fig. 3). Larger monthly differences in the soil temperature in spring, summer, and autumn in both catchments occurred on south-facing slopes (vs. north-facing), with the largest monthly dif- 

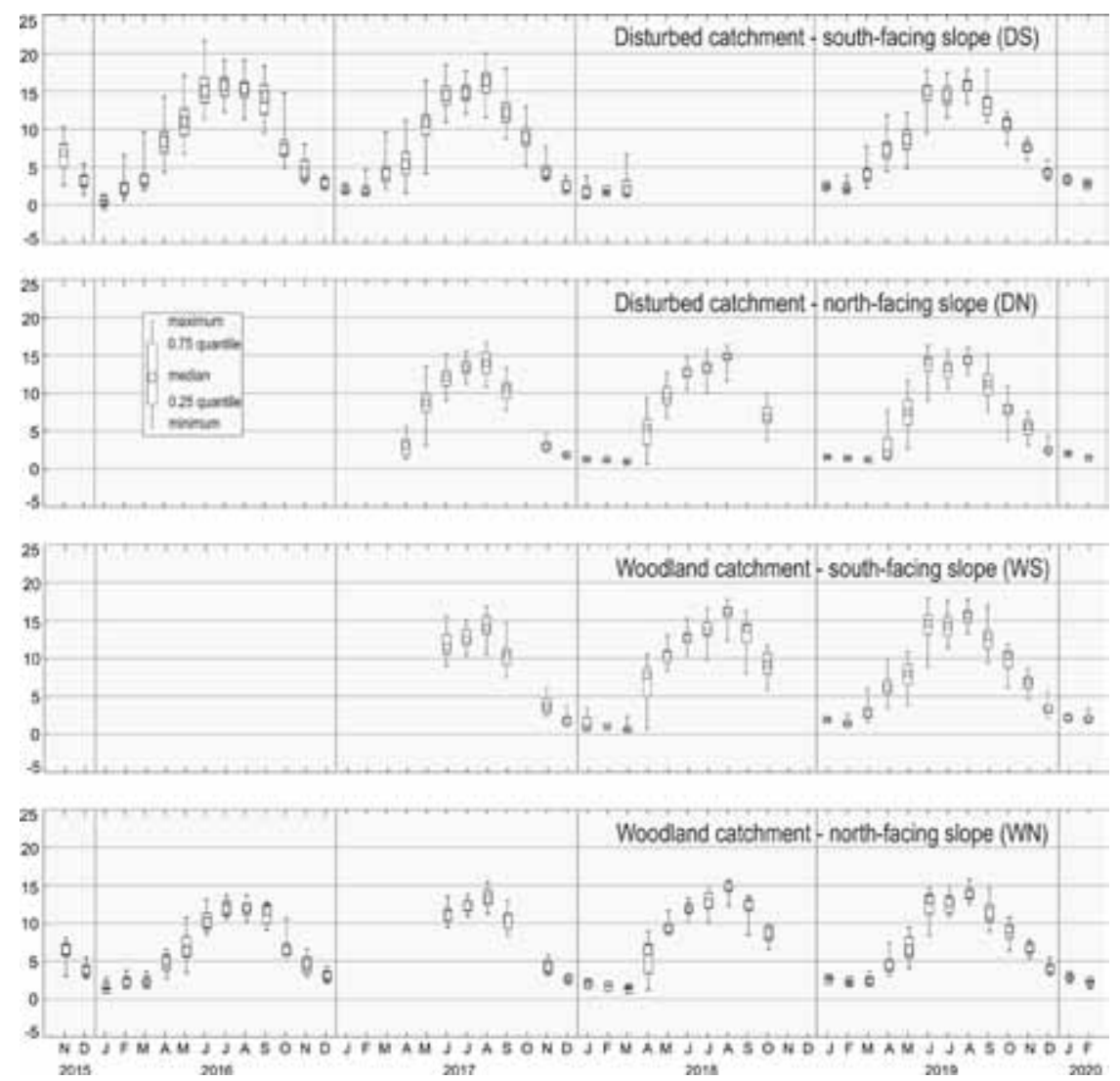

Fig. 3. Statistical characteristics of soil temperature at four studied sites for each month of the studied period (November 2015 - February 2020). The above statistics are based on raw data.

ferences in soil temperature noted at the DS site. The relationship between mean daily soil and air temperatures for a given month was stronger for south-facing slopes (DS and WS sites) than north-facing slopes (DN and WN sites). The strongest relationship was noted for the DS site and weakest for the WN site (Table 2). This relationship was strongest for all sites in the summer months and weakest in winter.

A comparison of soil temperature measured at the same time on south-facing slopes in the disturbed and woodland catchments (DS site vs. WS site) showed that in 2017 and early 2018 (January to March, lack of data for DS for subsequent months) the soil temperature at the DS site was much higher than at the WS site. Mean monthly soil temperatures in summer (June to August 2017) were from 1.8 to $2.4^{\circ} \mathrm{C}$ higher at the DS site than the WS site (Table 3 ). These differences were smaller in the winter. This pattern changed in 2019 when soil temperatures were often higher at the WS site than the DS site, especially in the summer (Fig. 4), and mean monthly soil temperatures at both study sites were comparable (Table 3).Acomparison of soil temperatures measured at the same time in both catchments on north-facing slopes (DN site versus WN site) showed that soil temperatures in the summer were higher at the DN site versus the WN site, while in the winter the situation was just the opposite - higher soil temperature values were noted for the WN site versus the DN site. This pattern was evidenced by mean monthly soil temperature data (Table 3).

Table 2. The Pearson correlation coefficient $(p \leq 0.05)$ between mean daily soil temperature and mean daily air temperature for four studied sites: DS - south-facing slope of the disturbed catchment, DN - north-facing slope of the disturbed catchment, WS - south-facing slope of the woodland catchment, WN - north-facing slope of the woodland catchment (ns - not significant).

\begin{tabular}{|c|c|c|c|c|}
\hline Year / month & DS & $\mathrm{DN}$ & WS & WN \\
\hline 2017/June & 0.804 & 0.614 & 0.833 & 0.645 \\
\hline 2017 / July & 0.845 & 0.644 & 0.758 & 0.443 \\
\hline 2017 / August & 0.874 & 0.618 & 0.748 & 0.487 \\
\hline 2017 / September & 0.774 & 0.628 & 0.707 & 0.572 \\
\hline 2017 / November & 0.565 & 0.516 & 0.657 & 0.502 \\
\hline 2017 / December & ns & -0.392 & ns & -0.395 \\
\hline 2018 / January & 0.479 & 0.375 & 0.444 & ns \\
\hline 2018/February & 0.765 & ns & 0.475 & 0.773 \\
\hline 2018 / March & 0.571 & ns & ns & -0.389 \\
\hline 2019/February & ns & ns & ns & ns \\
\hline 2019/March & 0.556 & ns & 0.490 & ns \\
\hline 2019/April & 0.788 & 0.492 & 0.737 & 0.441 \\
\hline 2019/ May & 0.830 & 0.795 & 0.802 & 0.599 \\
\hline 2019/June & 0.665 & 0.525 & 0.599 & 0.386 \\
\hline 2019/July & 0.798 & 0.730 & 0.722 & 0.602 \\
\hline 2019/August & 0.736 & 0.465 & 0.694 & ns \\
\hline 2019/September & 0.613 & 0.606 & 0.652 & 0.538 \\
\hline 2019 / October & 0.508 & 0.421 & 0.700 & 0.441 \\
\hline 2019/ November & ns & 0.453 & 0.508 & ns \\
\hline 2020 / January & ns & ns & ns & -0.364 \\
\hline 2020 / February & -0.405 & ns & ns & ns \\
\hline
\end{tabular}

In the springtime, soil temperatures first begin to increase at the DS site, with temperatures higher than 
$5{ }^{\circ} \mathrm{C}$ already in March. At other sites, soil temperatures begin to rise later, in April. The situation changed at the WS site in 2019 when the soil temperature at this site began to rise as quickly as that at the DS site (Fig. 3). A decrease in temperature in late autumn and winter below $5^{\circ} \mathrm{C}$ is first observed on north-facing slopes in the studied disturbed catchment.

Table 3. Mean monthly soil temperature $\left[{ }^{\circ} \mathrm{C}\right]$ at four studied sites: DS - south-facing slope of the disturbed catchment, DN - north-facing slope of the disturbed catchment, WS - southfacing slope of the woodland catchment, $\mathrm{WN}$ - north-facing slope of the woodland catchment.

\begin{tabular}{|c|c|c|c|c|}
\hline Year/month & DS & $\mathrm{DN}$ & WS & WN \\
\hline 2017 / June & 14.3 & 12.0 & 11.9 & 10.9 \\
\hline 2017 / July & 14.8 & 13.3 & 12.8 & 12.2 \\
\hline 2017 / August & 16.1 & 13.9 & 14.3 & 13.3 \\
\hline 2017 / September & 12.2 & 10.3 & 10.5 & 10.3 \\
\hline 2017 / November & 4.5 & 3.0 & 3.8 & 4.1 \\
\hline 2017 / December & 2.4 & 1.7 & 1.9 & 2.5 \\
\hline 2018/January & 1.8 & 1.2 & 1.5 & 1.9 \\
\hline 2018 / Fabruary & 1.6 & 1.1 & 1.0 & 1.6 \\
\hline 2018 / March & 2.4 & 0.8 & 0.9 & 1.3 \\
\hline 2019/January & 2.3 & 1.5 & 1.9 & 2.5 \\
\hline 2019/Fabruary & 2.1 & 1.3 & 1.4 & 2.0 \\
\hline 2019/March & 4.0 & 1.1 & 2.9 & 2.2 \\
\hline 2019/April & 7.3 & 2.9 & 6.2 & 4.5 \\
\hline 2019/May & 8.5 & 7.2 & 7.8 & 6.6 \\
\hline 2019/June & 14.6 & 13.7 & 14.5 & 12.4 \\
\hline 2019/July & 14.4 & 13.1 & 14.4 & 12.5 \\
\hline 2019/August & 15.7 & 14.2 & 15.6 & 13.7 \\
\hline 2019/September & 13.2 & 11.0 & 12.6 & 11.2 \\
\hline 2019 / October & 10.6 & 7.6 & 9.9 & 8.8 \\
\hline 2019 / November & 7.5 & 5.3 & 6.8 & 6.5 \\
\hline 2019 / December & 4.3 & 2.5 & 3.4 & 3.9 \\
\hline 2020 / January & 3.3 & 1.9 & 2.1 & 2.7 \\
\hline 2020 /Fabruary & 29 & 14 & 21 & 21 \\
\hline
\end{tabular}

\section{Discussion}

The effect of forest disturbance on the soil temperature at $20 \mathrm{~cm}$ depth in the study area is observable first and foremost via a rise in the soil temperature in the summer months. The mean soil temperature in the summer months on south-facing slopes in the disturbed catchment is 1.8 to $2.4^{\circ} \mathrm{C}$ higher than that in the woodland

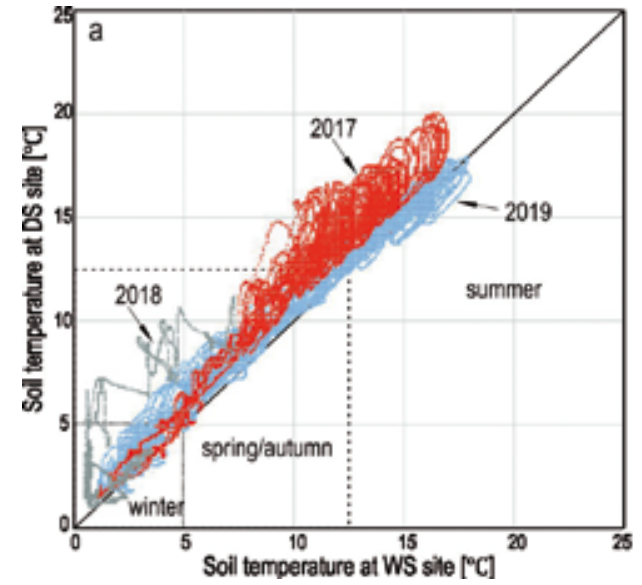

catchment. After partial disturbance on the south-facing slope of the woodland catchment in 2019, the mean monthly soil temperature increased and was comparable to that in the disturbed catchment in 2013 (Table 3). The soil temperature difference on the north-facing slopes of the woodland and disturbed catchments in summertime was smaller at about $1{ }^{\circ} \mathrm{C}$ (Table 3$)$. Higher soil temperatures in disturbed areas versus woodland areas in the summertime have been documented by many researchers in other parts of the world. The differences in mean soil temperatures described by these other researchers for the summer months between woodland and disturbed areas do vary mostly due to differences in the depth at which each measurement was performed. According to Paul et al. (2004) soil depth is the most important factor aside from other key factors such as air temperature and the surface area covered by tree canopies controlling soil temperature. Moroni et al. (2009) studied soil temperature at a depth of $10 \mathrm{~cm}$ in Newfoundland in Canada and found that the difference in the soil temperature between a harvested area and woodland area in the summer season equals about $2{ }^{\circ} \mathrm{C}$. Bhatti et al. (2000) showed in northeastern Ontario in Canada that soil temperature at a depth of $5 \mathrm{~cm}$ increases in the summer after harvesting by 4 to $6^{\circ} \mathrm{C}$. According to research by Hu et al. (2013) conducted in a steppe area in Central Asia, the soil temperature at a depth of $10 \mathrm{~cm}$ was higher by 4 to $8{ }^{\circ} \mathrm{C}$ relative to that in a woodland area in the warm season. Londo et al. (1999) studied soil temperature in Texas in the United States and found a marked increase in soil temperature after deforestation - the measurements were performed at a depth of $10 \mathrm{~cm}$ in the summer season. The increase in soil temperature was larger after clearcutting than after partial clearcutting (Londo et al. 1999).

According to Hashimoto \& Suzuki (2004) a marked increase in soil temperature following forest clear-cutting is associated with an increase in absorbed solar radiation. Soils in woodland areas are protected from heating not only by trees but also by the organic forest floor situated

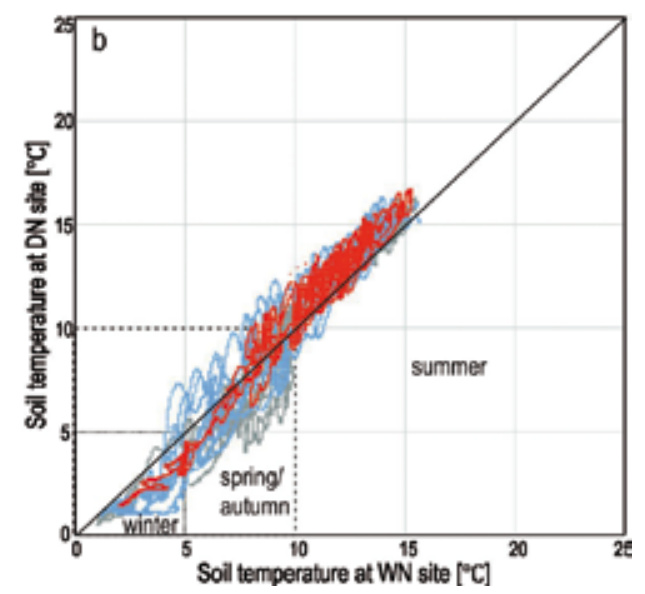

Fig. 4. Relationship between soil temperature (raw data) at DS site and WS site (A), and DN site and WN site (B) taking into account all measurements made in 2017 (red points), 2018 (grey points), and 2019 (blue points). 
atop the mineral soil horizons. The forest floor acts as a thermal insulator (Bhatti et al. 2000). The presented research has shown that an area without trees and an organic layer, such as a disturbed catchment, heats up more during the summer than a wooded area with an organic layer that is 1-5 centimeters thick, as would be the case in a woodland area. The buffer effect of forest on soil temperature is confirmed by lower coefficients of correlation between soil temperature and air temperature in a woodland catchment versus a disturbed catchment.

The effect of forest disturbance on soil temperature measured at a depth of $20 \mathrm{~cm}$ in the winter months in the catchments examined in the present study was weaker than that in the summer. Similar conclusions were reached by Donnelley et al. (1991) for the northeastern United States, Hashimoto \& Suzuki (2004) for Japan, and Moroni et al. (2009) for Newfoundland (Canada). Small differences in soil temperature in the winter between the woodland and disturbed areas examined in the present study were undoubtedly associated with the presence of snow cover and its capacity for thermal insulation. The thickness of the snow cover in the study period in the winter months usually reached into the tens of centimeters (Fig. 2c). The soil temperature is above freezing in winter months when mean daily air temperatures fall below $-5{ }^{\circ} \mathrm{C}$ and sometimes below $-20^{\circ} \mathrm{C}$. Short-term decline in soil temperature below $0{ }^{\circ} \mathrm{C}$ on a south-facing slope in the disturbed catchment could be due to the negligible thickness of snow cover, less than $10 \mathrm{~cm}$. It is possible that the snow simply melted on the south-facing slope in the disturbed catchment. Meng et al. (1995) observed that soil frost penetrates deeply into deforested wind-exposed soil, e.g. soil without snow cover. The relatively good insulation provided by snow cover to the soil separating it from the weather above yields only a poor correlation between soil temperature and air temperature in the winter - unlike that in the summer months. According to Mellander et al. (2005), snow depth together with snow thermal conductivity play an important role in the timing of soil warming in winter and spring.

Forest disturbance leads to an increase in the difference in soil temperature over the course of the year. On south-facing slopes, this is caused by a very large increase in soil temperature in the summer; in the winter months, soil temperatures are generally somewhat higher than those in the woodland catchment. However, on northfacing slopes, this is caused by a small rise in the soil temperature in summer and a small decline in winter. The presented research has confirmed the assertion by Hu et al. (2013) that the forest buffers the soil temperature by lowering the soil temperature during the warm season and increasing it during the cold season; however, this is only true of north-facing mountain slopes. What is puzzling is the phenomenon of higher soil temperatures on south-facing slopes in winter in the disturbed catchment versus the woodland catchment. This is most likely due to increased solar radiation in disturbed areas versus woodland areas, as shown by larger diurnal changes in the soil temperature on a south-facing slope in a disturbed catchment versus all other measurement sites (unpublished data).

Soil temperatures rise in spring $\left(>5^{\circ} \mathrm{C}\right)$, as early as March, in the disturbed catchment on south-facing slopes. At all other measurement sites, soil temperatures begin to increase only in April. Hu et al. (2013) studied soil temperature in Central Asia and observed that the spring thawing of soils occurs two weeks earlier in treeless areas (i.e. steppe) versus woodland areas. On the other hand, Whitson et al. (2005) studied soil temperatures in southwestern Canada and learned that land cover (harvested sites vs. forested sites) does not determine the timing of the spring soil thaw. Instead, slope exposure is the determining factor: the soil profiles of southerly aspect began thawing in mid-April, while those with northerly aspect in the latter half of May (Whitson et al. 2005). The presented research has shown that both land cover and slope exposure determine the timing of increases in soil temperature in spring. On south-facing slopes in disturbed areas, the snow cover disappears more rapidly than that on north-facing slopes as well as on woodland slopes. Soil on a disturbed, south-facing slope becomes devoid of snow earlier, on the one hand, and is not yet covered by young grass and bushes on the other. The lack of thermal insulation leads to increase the absorbed solar radiation triggering a rise in soil temperature. Mellander et al. (2005) assert that in years with thin snow cover there was the largest variation in the timing of soil warming (when soil temperature reaches $5^{\circ} \mathrm{C}$ ) in spring between stands of different age. In autumn, soil temperatures examined in the present study fall the earliest on north-facing slopes in the disturbed catchment due to both less absorbed solar radiation than on south-facing slopes and the absence of the buffer effect of forest.

The presented research represents a small step towards a better understanding that forest disturbance may lead to dangerous feedback loops in the atmosphere, pedosphere, and biosphere. The increase in soil temperature caused by forest disturbance will result in an increased release of greenhouse gases from the soil into the atmosphere. Soil temperature is a very important factor shaping methane emissions (Mikkela et al. 1995) and soil respiration - soil CO $\mathrm{CO}_{2}$ efflux (Davidson et al. 1998; Subke et al. 2003; Uvarov et al. 2006; Tang et al. 2008). For example, Hick Pries et al. (2017) noted an increase in $\mathrm{CO}_{2}$ loss of $34 \%$ to $37 \%$ from the first meter of the top mineral soil horizon with a rise of $4^{\circ} \mathrm{C}$ in soil temperature. The increase in greenhouse gas emissions will induce an increase in air temperature, which will result in a further increase in soil temperature and further tree mortality. Ney at al. (2019) note that forest management practices enacted following a natural forest disturbance are becoming an increasingly important part of climate change mitigation strategies. 


\section{Conclusions}

The effect of forest disturbance triggered by hurricaneforce winds on soil temperatures at a $20 \mathrm{~cm}$ depth in the Western Tatras in Poland is marked by an increase in the difference in the soil temperature over the course of the year. This is due first and foremost to a marked increase in soil temperature during the summer months. The mean soil temperature in the summer months on south-facing slopes in the studied disturbed catchment was 1.8 to $2.4{ }^{\circ} \mathrm{C}$ higher than that in the studied woodland catchment. On north-facing slopes, the difference in the soil temperature between the woodland catchment and disturbed catchment in the summer months was smaller at about $1{ }^{\circ} \mathrm{C}$. The presented research has confirmed the presence of the buffer effect of forest on soil temperature in summer, which is manifested by lower coefficients of correlation between soil temperature and air temperature in the woodland versus disturbed catchment.

The effect of forest disturbance on soil temperature in the winter months is less pronounced than in the summer months. This is associated with the presence of snow cover that acts as a thermal insulator. In the winter months (December-February) snow cover depth usually exceeds $20 \mathrm{~cm}$ in the studied area. Good insulation of the soil from the atmosphere by snow cover leads to a very weak relationship between soil temperature and air temperature in winter. The soil temperature on disturbed, north-facing slopes in the winter is lower than that on woodland, north-facing slopes. This suggests the presence of a buffer effect of forest on the soil temperature that increases the soil temperature during the colder season and decreases it in the warmer season, on northfacing slopes. However, it is puzzling that a south-facing slope in a disturbed catchment would exhibit slightly higher soil temperatures in winter than those in a woodland catchment. This is likely due to increased absorbed solar radiation on south-facing slopes in disturbed areas versus woodland areas. However, this finding requires further research.

The research has shown that land cover (i.e. forest vs. lack of forest) and slope exposure (south versus north) determine the timing of increases in soil temperature in spring and timing of soil temperature declines in autumn. In the spring season, soil temperatures increase the fastest (in March) on disturbed, south-facing slopes due to faster thawing of snow and absence of any vegetation such as young grasses or bushes. Given a low level of thermal insulation, one may expect increased absorbed solar radiation that leads to a rapid increase in soil temperature. In the autumn season, temperatures on the studied disturbed, north-facing slopes decrease at an earlier date than elsewhere due to less absorbed solar radiation than on south-facing slopes as well as the lack of the buffer effect of forest cover.

The present study shows that an increase in soil temperature triggered by forest disturbance may significantly intensify soil warming caused by climate warming. Moreover, forest disturbance will lead to dangerous feedback mechanisms. The increase in soil temperature caused by forest disturbance will cause increased emissions of $\mathrm{CO}_{2}$ from the soil to the atmosphere, which will contribute to an increase in air temperature. This will result in a further increase in soil temperature and the decline of some temperature sensitive tree stands. In order to minimize the soil warming effect triggered by forest disturbance, tree seedlings should be planted as soon as possible after forest disturbance. Moreover, this type of situation should be used to plant stands whose tree species composition corresponds to the natural habitat in a given climate zone in the mountains. Natural forest stands are believed to be more resistant to natural disasters such as hurricaneforce winds or bark beetle invasions than spruce monocultures frequently found in Central Europe.

\section{Acknowledgement}

The research was financed by the Jagiellonian University in Kraków, Institute of Geography and Spatial Management. The authors wish to thank Grzegorz Zębikfor his helpful advice and review of the English language of the manuscript.

\section{References}

Allen, C. D., 2009: Climate-induced forest dieback: an escalating global phenomenon? Unasylva, 231/232:43-49.

Allen, C. D., Macalady, A. K., Chenchouni, H., Bachelet, D., McDowell, N., Vennetier, M. et al., 2010:Aglobal overview of drought and heat-induced tree mortality reveals emerging climate change risks for forests. Forest Ecology and Management, 259:660-684.

Allen, M. R., Dube, O. P., Solecki, W., Aragón-Durand, F., Cramer, W., Humphreys, S. et al., 2018: Framing and Context. In: Masson-Delmotte, V., Zhai, P., Pörtner, H-O., Roberts, D., Skea, J., Shukla, P.R. et al. (eds): Global Warming of $1.5^{\circ} \mathrm{C}$. An IPCC Special Report on the impacts of global warming of $1.5^{\circ} \mathrm{C}$ above pre-industrial levels and related global greenhouse gas emission pathways, in the context of strengthening the global response to the threat of climate change, sustainable development, and efforts to eradicate poverty. Intergovernmental Panel on Climate Change.

Anderegg, W. R. L., Kane, J. M., Anderegg, L. D. L., 2013: Consequences of widespread tree mortality triggered by drought and temperature stress. Nature Climate Change, 3:30-36.

Bhatti, J., Fleming, R. L., Foster, N. W., Meng, F-R., Bourque, C. P. A., Arp, P., 2000: Simulations of pre- and post-harvest soil temperature, soil moisture, and snowpack for jack pine: comparison with field observations. Forest Ecology and Management, 138:413-426. 
Bodziarczyk, J., Szwagrzyk, J., Zwijacz-Kozica, T., Zięba, A., Szewczyk, J., Gazda A., 2019: The structure of forest stands in the Tatra National Park: The results of 2016-2017 inventory. Forest Research Papers, 80:13-21.

Cassardo, C., Park, S. K., Sungmin, O., Galli, M., 2018: Projected Changes in Soil Temperature and Surface Energy Budget Components over the Alps and Northern Italy, Water, 10:1-18.

Davidson, E. A., Janssens, I. A., 2006: Temperature sensitivity of soil carbon decomposition and feedbacks to climate change. Nature, 440:165-173.

Donnelly, J. R., Shane, J. B., Yawney, H. W., 1991: Harvesting causes only minor changes in physical properties of upland Vermont soil. Northern Journal of Applied Forestry, 8:33-36.

Gholami, V., 2013: The influence of deforestation on runoff generation and soil erosion (Case study: Kasilian Watershed). Journal of Forest Science, 59:272-278.

Hashimoto, S., Suzuki, M., 2004: The impact of forest clear-cutting on soil temperature: a comparison between before and after cutting, and between clearcut and control sites. Journal of Forestry Research, 9:125-132.

Hess, M., 1996: Klimat. In: Mirek, Z., Głowaciński, Z., Klimek, K., Piękoś-Mirkowa, H. (eds.): Przyroda Tatrzańskiego Parku Narodowego, Tatry i Podtatrze 3. Tatrzański Park Narodowy. Kraków-Zakopane, p. 53-68.

Hlásny, T., Kočický, D., Maretta, M., Sitková, Z., Barka, I., Konôpka, M., Hlavatá, H., 2015: Effect of deforestation on watershed water balance: hydrological modelling-based approach. Central European Forestry Journal, 61: 89-100.

Hu, G., Liu, H., Anenkhonov, O. A., Korolyuk, A. Y., Sandanov, D. V., Guo, D., 2013: Forest buffers soil temperature and postpones soil thaw as indicated by a three-year large-scale soil temperature monitoring in the forest-steppe ecotone in Inner Asia. Global and Planetary Change, 104:1-6.

$\mathrm{Hu}, \mathrm{Q}$., Feng, S., 2003: A daily soil temperature dataset and soil temperature climatology of the contiguous United States. Journal of Applied Meteorology, 42:1139-1156.

Iwahana, G., Machimura, T., Kobayashi, Y., Fedorov, A., Konstantinov, P., Fukuda, M., 2005: Influence of forest clear-cutting on the thermal and hydrological regime of the active layer near Yakutsk, Eastern Siberia. Journal of Geophysical Research, 110:G02004.

Jewett, K., Daugharty, D., Krause, H., Arp, P., 1995: Watershed responses to clear-cutting: effects on soil solutions and stream water discharge in central New Brunswick. Canadian Journal of Soil Science, 75:475-490.

Khaleghi, M. R., 2017: The influence of deforestation and anthropogenic activities on runoff generation. Journal of Forest Science, 63:245-253.
Likens, G. E., Bormann, F. H., Johnson, N. M., Fisher, D. W., Pierce, R. S., 1970: Effects of forest cutting and herbicide treatment on nutrient budgets in the Hubbard Brook Watershed-Ecosystem. Ecological Monographs, 40:23-47.

Londo, A. J., Messina, M. G., Schoenholtz, S. H., 1999: Forest harvesting effects on soil temperature, moisture, and respiration in a bottomland hardwood forest. Soil Science Society of America Journal, 63:637-644.

Martínez-Vilalta, J., Lloret, F., Breshear, D. D., 2012: Drought-induced forest decline: causes, scope and implications. Biology Letters, 8:689-691.

Mellander, P. E., Laudon, H., Bishop, K., 2005: Modelling variability of snow depths and soil temperatures in Scots pine stands. Agricultural and Forest Meteorology, 133:109-118.

Meng, F-R., Bourque, C-A., Jewett, K., Daugharty, D., Arp, P. A., 1995: The Nashwaak Experimental Watershed Project: analysing effects of clearcutting on soil temperature, soil moisture, snowpack, snowmelt and stream flow. Water, Air and Soil Pollution, 82:363-374.

Moroni, M., Carter, P., Ryan, D., 2009: Harvesting and slash piling affect soil respiration, soil temperature, and soil moisture regimes in Newfoundland boreal forests. Canadian Journal of Soil Science, 89:343355.

Ney, P., Graf, A., Bogena, H., Diekkrüger, B., Drüe, C., Esser, O. et al., 2019: $\mathrm{CO}_{2}$ fluxes before and after partial deforestation of a Central European spruce forest. Agricultural and Forest Meteorology, 274:61-74.

Paul, K. I., Polglase, P. J., Smethurst, P. J., O’Connell, A. M., Carlyle, C. J., Khanna, P. K., 2004: Soil temperature under forests: a simple model for predicting soil temperature under a range of forest types. Agricultural and Forest Meteorology, 121:67-182.

Schlesinger, W. H., Andrews, J. A., 2000: Soil respiration and the global carbon cycle. Biogeochemistry, 48:7-20.

Skiba, S., Koreň, M., Drewnik, M., Kukla, J., 2015: Soils. In: Dąbrowska, K., Guzik, M. (eds.): Atlas of the Tatra Mts. - Abiotic Nature. Tatrzański Park Narodowy. Zakopane, plate number: VI.1.

Steinkamp, J., Hickler, T., 2015: Is drought-induced forest dieback globally increasing? Journal of Ecology, 103:31-43.

Strzyżowski, D., Fidelus-Orzechowska, J., Żelazny, M., 2016: Geomorphological changes within a hillslope caused by a windthrow event in the Tatra Mountains, Southern Poland. Geografiska Annaler. Series A, Physical Geography, 98:347-360.

Szwagrzyk, J., Bodziarczyk, J., Pielech, R., Zieba, A., Zwijacz-Kozica, T., 2019: The impact of wind and bark beetle outbreaks and protective measures on the vegetation of spruce forests in the Tatra National Park. Parki Narodowe i Rezerwaty Przyrody, 38: 57-68. 
Ustrnul, Z., Walawender, E., Czekierda, D., Štastný, P., Lapin, M., Mikulová, K. 2015: Precipitation and snow cover. In: Dąbrowska, K., Guzik, M. (eds.): Atlas of the Tatra Mts. - Abiotic Nature. Tatrzański Park Narodowy. Zakopane, plate number: II.3.

Whitson, I., Chanasyk, D., Prepas, E., 2005: Effect of forest harvest on soil temperature and water storage and movement patterns on boreal plain hillslopes. Journal of Environmental Engineering and Science, 4:429-439.
Żelazny, M., Adamska, M., Ciemborowicz, M., FidelusOrzechowska, J., Gus, M., Jaśkowiec, B. et al., 2018: Ocena wpływu wielkoobszarowych wiatrołomów na reżim hydrochemiczny i denudację zlewni położonych w obszarach leśnych na terenach górskich (Tatry Polskie) - etap 4. Kraków, Raport K/KDU/000494,395 p.

Żmudzka, E., Nejedlík, P., Mikulová, K., 2015: Temperature, thermal indices. In: Dąbrowska, K., Guzik, M. (eds.): Atlas of the Tatra Mts. - Abiotic Nature. Tatrzański Park Narodowy. Zakopane, plate number: II.2. 